\title{
PENGUJIAN FREIES ERMESSEN ATAS LEGISLASI SEMU KEPALA DAERAH
}

\author{
Nehru Asyikin \\ Praktisi di Lembaga Bantuan Hukum Aksa Bumi Yogyakarta. Email: \\ nehruasyikin1@gmail.com
}

\begin{abstract}
ABSTRAK
Kebebasan membuat peraturan atau freies ermessen melalui Legislasi semu (aturan kebijakan tersebut) merupakan doktrin dalam hukum tata pemerintahan yang dikeluarkan eksekutif baik di pusat atau di daerah, namun beberapa legislasi semu berupa Surat Edaran Kepala Daerah yang menuai polemik di antaranya Surat Edaran Nomor 180/8883/2019 dan Surat Edaran Nomor 450/1/2020. Penelitian ini menggunakan penelitian hukum normatif dengan menggunakan pendekatan perundang-undangan dan konseptual. Hasil penelitian ini bahwa Kepala daerah diberikan hak konstitusional untuk menetapkan peraturan kebijakan, kepala daerah diberikan hak untuk membuat aturan bagi wilayah administratifnya berupa Surat Edaran (SE), Petunjuk Pelaksana Petunjuk Operasional atau Petunjuuk Teknis, Instruksi, Pengumuman. Pengujian dapat dilakuakn dengan menggunakan asas-asas umum pemerintah yang layak yang dilakukan oleh peradilan tata usaha negara Sedangkan unsur yang diuji adalah dengan diuji dengan asas rasionalitas atau kepantasan dan secara isi substansi bertentangan dengan peraturan perundang-undangan yang berlaku. Sedangkan peraturan kebijakan tidak memuat sanksi berupa sanksi pidana, sanksi pemaksa, hal ini karena peraturan kebijakan tidak memuat sanksi tersebut karena sanksi tersebut hanya boleh di muat dalam undang-undang dan peraturan daerah (Perda). Peraturan kebijkana boleh mencantumkan sanksi dalam isi substansinya hanya sebatas sanksi administratif
\end{abstract}

Kata-kata kunci : Legislasi Semu; Freies Ermessen; Kepala Daerah

\begin{abstract}
Freies ermessen through pseudo legislation (the policy rules) are doctrines in governance law issued by the executive both at the center or in the regions, but some pseudo legislation in the form of Circular of Regional Heads reaps polemics including Circular Letter Number 180/8883/2019 and Letters Circular Number 450/1/2020. This study uses normative legal research using a statutory and conceptual approach. The results of this study that the Regional Head is given constitutional rights to establish policy regulations, the Regional Head is given the right to make rules for his administrative area in the form of Circular (SE), Implementing Instructions for Operational Instructions or Technical Guidance, Instructions, Announcements. testing can be carried out by using appropriate general government principles carried out by the state administrative court. While the element being tested is by being tested with the principle of rationality or appropriateness and the contents of the substance of the dictum are contrary to the applicable laws and regulations. While policy regulations do not contain sanctions in the form of criminal sanctions, coercive sanctions, this is because policy regulations do not contain sanctions because these sanctions may
\end{abstract}


only be contained in local laws and regulations (Perda). Policy regulations may include sanctions in the substance of the substance only limited to administrative sanctions.

Keywords: Pseudo Legislation; Freies Ermessen; Regional Head

\section{PENDAHULUAN}

Menurut Undang-Undang Nomor 23 Tahun 2014 tentang Pemerintahan Daerah Pasal 1 huruf b menjelaskan Pemerintahan Daerah adalah penyelenggaraan urusan pemerintahan oleh pemerintah daerah dan dewan perwakilan rakyat daerah menurut asas otonomi dan tugas pembantuan dengan prinsip otonomi seluas-luasnya dalam sistem dan prinsip Negara Kesatuan Republik Indonesia sebagaimana dimaksud dalam Undang-Undang Dasar Negara Republik Indonesia Tahun 1945. Meskipun secara konstitusional pemerintah daerah diberikan wewenang langsung dari UUD 1945 Pasal 18 ayat (2) berbunyi: Pemerintah daerah provinsi, daerah Kabupaten, dan Kota mengatur dan mengurus sendiri urusan pemerintahan menurut asas otonomi dan tugas pembantuan. Namun wewenang konstitusional itu dapat dikatakan sebagai wewenang mengatur dan mengurus sendiri apabila setiap tindakan dan keputusan pemerintah tidak boleh bertentangan dengan konstitusi dan peraturan perundang-undangan di bawahnya.

Hal ini karena meskipun diperintahkan oleh konstitusi tetapi tidak menutup kemungkinan tindakan atau keputusan bertentangan dengan kemaslahatan umum apalagi karena yang menjalankan adalah manusia yang sifatnya dapat dapat pula mengarah kepada Political kickbacks, yaitu kegiatan-kegiatan yang berkaitan dengan sistem kontrak pekerjaan borongan antara pejabat pelaksana dan pengusaha yang memberi peluang untuk mendatangkan banyak uang bagi pihak-pihak yang bersangkutan. Maupun karena wewenang itu mengarah kepada Discretionary corruption yaitu korupsi yang dilakukan karena ada kebebasan dalam menentukan kebijakan. Apalagi pejabat di daerah cenderung menjadi raja kecil di wilayah administrasinya dan tindakan atau keputusannya selalu dianggap sah meski tidak tepat sasaran. Maka dapat diartikan bahwa posisi pemerintah ditempatkan sebagai pemegang remot kontrol atas kepentingan masyarakat yang berdasarkan wewenangnya menurut undang-undang yang waktu itu menerima wewenang tersebut untuk dijalankan atas kepentingan-kepentingan yang dihadapkan kepadanya. 
Secara hukum tentang pemerintahan daerah. Seorang Kepala Daerah yang mengggunakan freies ermessen dalam suatu pengambilan kebijakan tidak dapat diminta pertanggungjawaban pidananya, apabila dalam mengambil atau menetapkan keputusan tersebut tidak ada suatu kickback yang diakibatkan penyalahgunaan wewenang menyiratkan sikap batin yang mengiringi perbuatan tersebut bertujuan memperkaya atau menguntungkan diri sendiri. (Ridwansyah, 2018). Pada kenyataan sehari-hari, badan atau pejabat Tata Usaha Negara seringkali menempuh berbagai langkah kebijakan tertentu, antara lain menciptakan apa yang sering dinamakan aturan kebijakan (beleidsregel, policy rule). Produk semacam ini tidak terlepas dari kaitan penggunaan freies ermessen, yaitu badan atau pejabat Tata Usaha Negara yang bersangkutan merumuskan kebijakan dalam pelbagai bentuk seperti peraturan, pedoman, pengumuman, dan surat edaran. Suatu aturan kebijakan pada hakekatnya merupakan produk dari perbuatan tata usaha negara, namun tanpa disertai kewenangan pembuatan peraturan dari badan atau pejabat tata usaha negara tersebut. Aturan kebijakan dimaksud pada kenyataannya telah merupakan bagian dari kegiatan pemerintahan. Aturan kebijakan juga ditandai dengan sebutan pseudowetgeving atau legislasi semu.(Keuangan, 2014).

Legislasi semu tidak berdasarkan kepada suatu ketentuan perundang-undangan yang tegas (uitdrukkelijke bepalingen) memberikan kewenangan kepada pemerintah untuk membentuk atau menerbitkannya. Ini berarti legislasi semu tidak perlu menyebutkan dasar pertimbangan yang secara tegas (eksplisit) memerintahkan pembentukan legislasi tersebut. Pemberian kewenangan mengeluarkan legislasi semu (aturan kebijakan tersebut) merupakan doktrin dalam hukum tata pemerintahan (bestuursrechtelijke doctrine) yang menegaskan bahwa suatu organ pemerintahan dibolehkan memiliki kewenangan secara implicit (inplicite bevoegdheid) untuk menyusun aturan kebijakan (beleidsregels) dalam rangka menjalankan tugas umum pemerintahan. (Salim, 2020). Namun beberapa legislasi semu berupa Surat Edaran Kepala Daerah yang menuai polemik di antaranya Surat Edaran Nomor 180/8883/2019 Gubernur Sumatera Utara mengenai larangan kepada Aparat Sipil Negara (ASN) untuk menghadiri permintaan keterangan atau surat panggilan dari penyidik Kepolisian RI, Kejaksaan RI maupun Komisi Pemberantasan Korupsi (KPK) tanpa izin 
Gubernur.(Damanik, 2019)Kemudian Surat Edaran Nomor 450/1/2020 Bupati Demak tentang Tidak Bertamu Jelang Magrib hingga Isya yang ditujukan terhadap seluruh Aparatur Sipil Negara di wilayah kabupaten Demak. (Safuan, 2020).

Menurut doktrin atas tindakan atau keputusan pemerintah itu, di dalam pergaulan sehari-hari mungkin terjadi peristiwa-peristiwa yang membawa akibat-akibat hukum. Oleh van Apeldoorn peristiwa tersebut dirumuskan sebagai kejadian yang menimbulkan atau menghapuskan hak maupun kewajiban. Jadi suatu peristiwa hukum merupakan suatu peristiwa sosial yang bersegi hukum. Suatu peristiwa hukum mungkin berupa perikelakuan dalam hukum, yaitu perikelakuan atau sikap tindak yang mempunyai akibat hukum. dan terdiri dari perikelakuan menurut hukum (recht gedraging). (Soemardi, 2017).

Pada kebiasaan pemerintahan Indonesia untuk mengeluarkan kebijakan diharuskan melalui peraturan perundang-undangan manakala kebijakan tersebut dikeluarkan untuk dan demi kepentingan masyarakat umum tetapi dapat menyimpanginya dengan catatan sama sekali tidak ada norma di dalam peraturan perundang-undangan yang dimaksudkan. Hal ini karena pada konsep freies ermessen adalah asas yang bertujuan untuk mengisi kekurangan atau melengkapi asas legalitas supaya cita-cita negara hukum kesejahteraan dapat diwujudkan karena asas ini memberikan keleluasaan bertindak kepada pemerintah, untuk melaksanakan tugas-tugasnya tanpa terikat kepada undang-undang. (Abdul Rasyid Thalib dan Rahmat Bakri, 2013). Dalam praktik penyelenggaraan pemerintahan, Freies Ermessen dilakukan administrasi karena peraturan perundang-undangan yang menjadi dasar berbuat bagi aparat pemerintah dengan memberikan kebebasan sepenuhnya sehingga ada kepastian hukum agar aparat pemerintah diberi kewenangan untuk mengatur sendiri yang sebenarnya merupakan kewenangan aparat yang lebih tinggi tingkatannya. Pengambilan keputusan dan/atau tindakan karena adanya stagnasi pemerintahan guna kepentingan yang lebih luas. (Yudhi Setiawan, 2017: 143-144).

Konsekuensi sebagai Negara hukum modern dan kemajuan teknologi, disertai dengan krisis yang berkepanjangan di berbagai bidang, semakin menarik peranan Negara dan Pemerintah Indonesia memasuki bidang-bidang kehidupan dan pergaulan masyarakat, terutama pada 
penyelenggaraan kesejahteraan warga masyarakat. Tuntutan pelaksanaan kesejahteraan rakyat mengakibatkan kekuasaan pemerintah tidak mungkin lagi dapat dikungkung semata-mata melaksanakan wewenang yang didasarkan kepada undang-undang disamping berlakunya asas legalitas. Untuk mencapai hasil yang lebih baik pemerintah membutuhkan kebebasan untuk bertindak sendiri yang dikenal dengan Freies Ermessen. (Fitria, 2009). Berdasarkan penjelasan dari pendahuluan di atas, maka permasalahan yang dapat di rumuskan dalam tulisan ini adalah apa parameter pengujian Freies Ermessen atas legislasi semu kepala daerah.

\section{METODE PENELIITIAN}

Penelitian ini menggunakan penelitian hukum normatif dengan memanfaatkan bahan hukum primer, bahan hukum sekunder dan bahan hukum tersier dengan menggunakan pendekatan perundang-undangan dan konseptual. Dalam riset ini penulis hendak menganalisa dari segi hukum atau peraturan perundang-undangan melalui bahan hukum primer berupa peraturan perundang-undangan yang terkait pokok persoalan, kemudian memanfaatkan sekunder buku-buku yang berisi doktrin-doktrin dari para ahli hukum di bidang administrasi pemerintahan, jurnal-jurnal hokum berupa hasil riset yang dikomparasi agar peneliti dalam risetnya dan melihat perbandingan dan menghindari kesamaan dalam pengkajiannya nanti dan hasil penelitian tesis dan disertasi yang memiliki kajian yang sama dengan penulis.

\section{HASIL DAN PEMBAHASAN}

1. Paramter Pengujian Freies Ermessen atas Legislasi Semu Kepala Daerah

Tujuan Negara Republik Indonesia dipatrikan dalam alenia keempat Pembukaan Undang-Undang Dasar Tahun 1945. Undang-Undang Dasar dalam Pembukaannya dirumuskan tujuan negara merupakan objek kajian hukum tata negara, sedangkan operasionalisasi mewujudkan tujuan negara tersebut merupakan objek kajian hukum administrasi negara. Dengan demikian, hukum administrasi Indonesia merupakan yuridische instrumentarium untuk mewujudkan tujuan negara Republik Indonesia. (Marbun, 2018: 67-68). Sedangkan wewenang konstitusional yang diberikan kepada jabatannya dan keberadaannya ditentukan dengan tegas dalam UUD 1945 Pemerintah Daerah Provinsi, Gubernur Kepala Pemerintahan Daerah, Dewan Perwakilan Rakyat Daerah Provinsi, Pemerintah Daerah 
Kabupaten, Dewan Perwakilan Rakyat Daerah Kabupaten, Bupati Kepala Pemerintahan Daerah Kabupaten, Pemerintah Daerah Kota, Walikota Kepala Pemerintahan Daerah Kota, Dewan Perwakilan Rakyat Daerah Kota.

Ketentuan Pasal 18 UUD 1945 pertama, adanya daerah otonomi dalam penyelenggaraan pemerintah daerah yang didasarkan pada asas desentralisasi. Kedua, satuan pemerintahan tingkat daerah menurut UUD 1945 dalam penyelenggaraannya dilakukan dengan "memandang dan mengingati dasar permusyawaratan dalam sistem pemerintah negara". Ketiga, pemerintahan tingkat daerah harus disusun dan diselenggarakan dengan "memandang dan mengingati hak-hak asal-usul dalam daerah yang bersifat istimewa".(Huda, 2014: 304)

Sejalan dengan hal di atas, pemerintah daerah berhak menetapkan peraturan daerah dan peraturan lain untuk melaksanakan otonomi dan tugas pembantuan, hal ini tertuang dalam Pasal 18 Ayat (6) Undang-Undang Dasar 1945, artinya kewenangan pemerintah daerah dalam hal ini adalah eksekutif, yaitu kepala daerah, Gubernur, bupati dan walikota memilik hak dan kewenangan untuk mengeluarkan suatu produk hukum bersama DPRD provinsi atau kabupaten dan kota. Sedangkan mengenai peraturan kebijakan, kepala daerah diberikan hak untuk membuat aturan bagi wilayah administratifnya.

Peraturan kebijakan tersebut merupakan suatu kebutuhan dalam rangka penyelenggaraan pemerintahan. Di Belanda, peraturan kebijakan dianggap sebagi instrumen penting di dalam hukum administrasi Belanda yang disebutan pseudowetgeving atau legislasi semu. Menurut Bagir Manan dan Kuntana Magnar dalam buku Beberapa Masalah Hukum Tata Negara Indonesia (1997) menyatakan, bahwa dalam kepustakaan Belanda, ada berbagai istilah yang dipergunakan untuk menunjukkan eksistensi peraturan kebijakan, antara lain dengan pseudowetgeving, spiegelrecht, dan beleidsregel (Chakim, 2019). Dalam praktek pemerintahan sehari-hari legislasi semu dapat diterbitkan oleh semua badan atau organ pemerintahan baik di tingkat pusat maupun daerah. Umumnya format dan nomenklatur yang dipakai untuk legislasi semu berbeda dengan peraturan perundang-undangan, walaupun dapat pula dijumpai substansi legislasi semu dituangkan dalam format perundang-undangan. Tidak ada suatu format baku yang digunakan dalam pembentukan legislasi semu. Beberapa 
contoh yang populer legislasi semu dapat dikemukakan sebagai berikut: (Salim, 2020)

a. Surat Edaran (SE), biasanya digunakan oleh seorang pejabat (menteri atau direktur jenderal) untuk memberitahukan kepada jajaran di bawahnya mengenai suatu kebijakan yang harus dilaksanakan yang berkaitan dengan pelayanan publik. Di lingkungan perpajakan (sebelum lahirnya UU Ketentuan Umum Perpajakan yang baru) banyak terdapat Surat Edaran Direktur Jenderal Pajak, yang mengatur berbagai persoalan teknis perpajakan. Demikian pula di lingkungan Departemen Hukum dan HAM, dapat dikemukakan adanya Surat Edaran Direktur Jenderal Administrasi Hukum Umum yang mengatur tentang tata cara pendaftaran fidusia sebagai pedoman bagi Kantor Wilayah Departemen Hukum dan HAM dalam memberikan pelayanan publik mengenai pendaftaran akta jaminan fidusia.

b. Petunjuk Pelaksana, yang dikeluarkan oleh pejabat sebagai pedoman bagi bawahan untuk melaksanakan peraturan tertentu yang termasuk dalam tugas pokok dan fungsinya.

c. Petunjuk Operasional atau Petunjuk Teknis yang memuat berbagai cara teknis adminstratif dan operasional mengenai tugas tertentu.

d. Instruksi yang dikeluarkan oleh pimpinan yang bersifat perintah untuk menjalankan tugas tertentu.

e. Pengumuman, yang antara lain berisi informasi yang diperlukan bagi masyarakat yang berkepentingan mengenai suatu pelayanan publik yang disediakan oleh instansi pemerintah.

Penjelasan di atas menunjukkan bahwa pada dasarkanya provinsi dan kabupaten bisa melakukan tindakan dan/atau keputusan sebagaimana dimaksudkan di dalam Konstitusi di atas. Sedangkan bagi perbuatan administrasi atau tindakan/keputusan tersebut menurut Safri Nugraha, ada empat macam perbuatan-perbuatan hukum Administrasi Negara masa kini, yaitu:

a. Penetapan (Beschiking, administrative discretion);

b. Rencana (Plan);

c. Norma labaran (Concrete normageving);

d. Legislasi Semu (Pseudo - wetgeving)

Di dalam praktek ketiga hal itu dilakukan secara kombinasi. yang bertalian erat dengan asas-asas desentralisasi, dekonsentrasi dan tugas 
pembantuan, serta dalam operasionalisasinya berbaur satu dengan yang lainnya. Dalam hal adanya delegasi kewenangan membuat keputusan harus didasarkan pada suatu undang-undang formal, setidak-tidaknya apabila keputusan itu memberikan kewajiban-kewajiban di atas para warga (masyarakat). (Nugraha, 1997).

Kebebasan pembentuk undang-undang tersebut dapat dipersamakan dengan tugas menyelenggarakan kesejahteraan umum atau freies Ermessen, yaitu kewenangan yang sah untuk turut campur dalam kegiatan melaksanakan tugas-tugas menyelenggarakan kepentingan umum. Tercakup pula dalam pengertian freies Ermessen membuat peraturan tentang hal-hal yang belum ada pengaturannya, atau mengimplementasikan peraturan yang ada sesuai dengan kenyataan. Pencakupan demikian disebut discretionary power (Radita Ajie, 2016).

Sedangkan pada wilayah penyelesaian sengketa atas terbitnya peraturan kebijakan menurut Ihsan Badruni Nasution, (2014) masih menjadi sebuah permasalahan karena tidak ada lembaga yang berhak untuk menguji peraturan kebijakan. Dalam kerangka negara hukum yang mengedepankan adanya kepastian hukum tentunya tidak bijak jika membiarkan suatu sengketa atas peraturan kebijakan berada di wilayah yang tidak jelas (grey area). Untuk mengantisipasi terjadinya kasus seperti ini, maka Mahkamah Agung dapat mengedepankan suatu asas hukum acara yang berlaku universal yaitu asas ius curia novit.

Peraturan kebijakan atas dasar freies Ermessen yang di keluarkan oleh Kepala Daerah memuat unsur-unsur yang menurut Safri Nugraha maka keputusan yang diambil akan mencerminkan: (Nugraha, 1997)

a. Keputusan yang realistis, artinya sesuai dengan situasi dan kondisi lokal;

b. Keputusan yang lebih baik kualitas, baik hasilnya maupun prosedurnya. dibandingkan bila keputusan tersebut diputuskan oleh pusat (Departemen

c. Perhubungan);

d. Kecepatan dan ketepatan prosedur pengambilan keputusan dengan tersebarnya pusat-pusat pengambilan keputusan dan lebih tahunya pusat-pusat pengambilan keputusan tersebut dengan situasi dan kondisi lokal yang ada; 
e. Sempurna atau kurang sempurna kegiatan manajemen di suatu organisasi pemerintahan;

f. Kepercayaan pusat (Departemen Perhubungan) kepada instansi vertikal di daerah, dan dengan demikian akan mendorong instansi vertikal lebih maju, "mandiri", lebih kreatif.

Pengawasan terhadap bentuk-bentuk peraturan sebagai produk eksekutif atau executive acts sangat perlu diawasi baik proses pembentukannya maupun pelaksanaannya dalam praktik. Pengawasan itu penting agar tidak menimbulkan ketidakadilan ataupun menimbulkan ketidakharmonisan antar norma hukum yang pada gilirannya dapat pula menimbulkan ketidakpastian hukum dan ketidakadilan hokum (Nugraha, 1997). Eksekutif melalui menteri-menteri yang bersangkutan melakukan pengawasan terhadap daerah melalui surat edaran yaitu pengawasan terhadap produk hukum kepala daerah yang mengeluarkan surat edaran kepala daerah di provinsi maupun kabupaten/kota dengan mengeluarkan surat edaran. Sebagai peraturan kebijakan agar terselanggaranya pemerintahan yang baik, setiap kebijakan yang dilakukan oleh pemerintah daerah povinsi maupun kabupaten harus di awasi oleh pusat melalui peraturan yang berada di atasnya dalam hal ini peraturan menteri.

Tidak ada otonomi tanpa pengawasan. Antara kemandirian otonomi dan pengawasan merupakan satu kesatuan yang tidak dapat dipisahkan. Pengawasan merupakan "pengikat" kesatuan agar bandul kebebasan berotonomi tidak terlepas begitu jauh mengurangi dasar negara kesatuan. Agar otonomi tidak menciptakan suatu keadaan anarkis, maka harus selalu ada cara-cara pengendalian yang menempatkan kebebasan tersebut di bawah kepentingan yang bersifat nasional.(Manan, 2001: 186) Kekuasaan yang sah menurut hukum atau kekuasaan hukum suatu jabatan, dan mengandung arti kemampuan untuk melakukan tindakan-tindakan hukum tertentu, serta bersumber pada undang-undang atau peraturan perundang-undangan yang berlaku. Jika organ pemerintahan mendapatkan kewenangan secara langsung dari undang-undang, berarti organ pemerintahan itu memperoleh kewenangan atas dasar atribusi (attributie).(Ridwan HR, 2009: 42)

Ruang lingkup tugas administrasi atau pemerintahan negara mencakup banyak bidang, sehingga apa yang dimaksud sebagai adminsitrasi negara Indonesia itu mengandung hal-hal sebagai berikut: (1) 
Tata pelaksanaan undang-undang; (2) Pengurusan rumah tangga negara yang diterapkan oleh undang-undang sebagai urusan Negara; (3) Tata usaha negara yang meliputi surat-menyurat, rahasia dinas dan jabatan, kearsipan dan dokumentasi, pelaporan dan statistik, tata cara penyimpanan berita acara, pencatatan sipil, pencatatan nikah, talak, dan rujuk publikasi penerbitan-penerbitan negara. (S. F. Marbun dan Mahfud MD, 2011: 53)

Sedangkan dalam peraturan kebijakan sanksi pidana dan sanksi pemaksa yang jelas mengurangi dan membatasi hak-hak asasi warga negara dan penduduk hanya dapat dituankan dalam undag-undang yang pembentukannya harus dilakukan dengan persetujuan rakyat dengan persetujuan wakil-wakilnya. Peraturan perundang-undangan yang lebih rendah hanya dapat mencantumkan sanksi pidana bagi pelanggaran ketentuannya apabila hal itu secara tegas datribusikan oleh undang-undang. Peraturan kebijakan hanya dapat mencantumkan sanksi administratif bagi pelanggaran ketentuan-ketentuannya (Ridwan HR, 2017 : 181)

Sebagai pelaksana dari undang-undang tersebut, pejabat daerah dan pegawan aparatur sipil negara bertugar melakukan kegiatan-kegiatan administrasi. Tujuannya adalah selain menjadi pengerak birokrasi, juga menjadi pelayan masyarakat dan memberikan kesejahteraan yang cenderung kepentingan masyarakat adalah untuk memajukan penghidupannya dengan meminta izin usaha kepada pemerintah daerah, melakukan pembayaran pajak yang ditetapkan oleh pemerintah daerah dan memenuhi syarat administrasi yang hanya bisa dikeluarkan oleh pemerintah daerah, seperti pengurusan Surat Keterangan Catatan Sipil, pembuatan Kartu Tanda Penduduk dan lain sebagainya untuk keperluan pengangkatan ekonominya. Bidang penyelenggaraan kesejahteraan umum tersebut patut dikemukakan pendapat Tatiek Sri Djatmiati berikut ini:

"peningkatan pelayanan publik harus mendapatkan perhatian utama dari pemerintah, karena pelayanan publik (public service) merupakan hak-hak sosial dasar dari masyarakat (social rights). (Ridwan HR, 2014: 85-86)

Pada dimensi lain, perbuatan pemerintah yang penting bagi hukum adminsitrasi negara adalah golongan perbuatan hukum (rechts handelingen), sebab perbuatan tersebut langsung menimbulkan akibat hukum tertentu 
bagi hukum adminsitrasi negara. Perbuatan pemerintah yang termasuk golongan perbuatan hukum dapat berupa: 1) Perbuatan hukum menurut hukum privat (sipil); 2) Perbuatan hukum menurut hukum publik (S. F. Marbun dan Mahfud MD, 2011 : 68)

Menurut United Nation Development Programme (UNDP) dalam Nur Rohim Kebijakan strategis untuk pencerahan kehidupan masyarakat yang dilakukan dengan Responsiveness (responsif); setiap unsur pemerintah harus memiliki dua etika, etika individual menuntut pelaksanaan birokrasi pemerintah agar memiliki kriteria kapabilitas dan loyalitas professional dan etika sosial menuntut mereka agar memiliki sensitivitas terhadap berbagai kebutuhan public. Sedangkan pada pengambilan kebijakan para pejabat pada tingkatan tertentu dapat mengambil kebijakan secara personal sesuai batas kewenangannya, tetapi menyangkut kebijakan kebijakan penting dan bersifat publik harus diputuskan secara bersama dengan seluruh unsur terkait. Kebijakan individual hanya dapat dilakukan sebatas menyangkut teknis pelaksanaan kebijakan, sesuai batas kewenangannya (Yunus, 2016).

Proses penerapan hukum (asas-asas umum pemerintahan yang layak) dalam penyelesaian sengketa di pengadilan administrasi (dari pemeriksaan perkara sampai pada pengambilan putusan) paling tidak melalui tiga tahapan seperti di bawah ini:

a. Penelitian administrasi oleh staf kepaniteraan diikuti oleh proses dismissal dan pemeriksaan persiapan. Setelah proses ini selesai dilanjutkan dengan pemeriksaan siding biasa dengan hakim majlis atau hakim tunggal. Pada tahap inilah yang disebut tahap pengumpulan fakta. Tugas hakim adalah melakukan seleksi terhadap keseluruhan peristiwa dan melakukan pembuktian dengan alat-alat bukti yang tersedia, guna memastikan kebenarannya;

b. Hakim adminstrasi melakukan suatu penilaian/pengujian terhadap fakta hukum atau peristiwa hukum yang sudah dikonstatirnya, kemudian dikualifisir masuk pada hubungan hokum mana. Berarti hakim sudah masuk pada tahap penerapan hukum (termasuk penerapan asas-asas umum pemerintahan yang layak), atau secara metodologis memasuki langkah deduktif. Langkah awalnya hakim melakukan identifikasi aturan hukum dan melakukan interpretasi 
terhadap aturan hukum yang sekiranya dapat diterapkan dalam, peristiwa konkrit;

c. Hakim administrasi teleaah mengetahui pokok sengketanya, juga sudah memberikan pertimbangan hukum mengenai penerapan asas-asas umum pemerintahan yang layak. Dengan demikian, hakim administrasi tinggal menentukan apakah keputusan administrasi negara yang disengketakan itu bertentangan dengan asas-asas umum pemerintahan yang layak atau tidak dan asas mana dari asas-asas umum pemerintahan yang layak yang dilanggar. Setelah itu hakim administrasi dapat menentukan keabsahannya keputusan administrasi negara melalui putusannya.(Syuhudi, 2017)

Dengan kata lain, kebijakan pemerintah akan dikategorikan sebagai kebijakan yang menyimpang jika di dalamnya ada unsur penyalahgunaan wewenang dan unsur sewenang-wenang. Ada tidaknya unsur penyalahgunaan wewenang diuji dengan asas spesialitas (specialiteitsbeginsel). Asas spesialitas ini mengandung arti bahwa wewenang itu diberikan kepada organ pemerintahan dengan tujuan tertentu. Menyimpang dari tujuan diberikannya wewenang akan dianggap sebagai penyalahgunaan wewenang. Adapun unsur sewenang-wenang diuji dengan asas rasionalitas atau kepantasan (redelijk). Suatu peraturan kebijakan dikategorikan mengandung unsur willekeur jika peraturan kebijakan itu nyata-nyata tidak masuk akal tidak beralasan (kennelijk onredelijk).(Ridwan HR, 2017: 185) Secara meterial atau substansial adalah keputusan yang isinya atau dictum bertentangan dengan peraturan perundang-undangan yang berlaku. Asas-asas umum pemerintahan yang baik dapat dimasukkan adalah asas larangan sewenang-wenang (willekeur) (Marbun, 2018: 336).

Pada prinsipnya, suatu kebijakan merupakan persoalan kebebasan kebijakan atau beleidvrij heid atau freies emessen dari aparatur negara dalam melaksanakan tugas publiknya, sehingga tidak dapat dinilai oleh hakim pidana atau hakim perdata. Freies Ermessen digunakan oleh pejabat/penyelenggara negara untuk bertindak dalam rangka penyelesaian keadaan negara dan mendesak yang timbul dan dihadapi dalam praktek penyelenggaraan negara, serta harus dijalankan demi tercapainya tujuan negara. Tolok ukur pembatasan penggunaan pembatasan penggunaan Freies Ermessen adalah parameter asas-asas umum pemerintahan yang baik. 
Kebijakan-kebijakan tersebut hanya tunduk dan dinilai dari segi hukum administrasi dan HTN, tidak dapat dinilai oleh hakim baik dari segi penerapan hukum publik (hukum pidana), maupun dari segi hukum privat (hukum perdata), karena kebijakan administrasi ini parameter hukumnya hanya boleh dinilai dari aspek rechtmatigheid dan bukan doelmatigheid. Menurut Marbun, tulisan ini terbalik, seharunya hanya boleh dinilai dari aspek doelmatigheid dan bukan dari aspek rechtmatigheid (IKAHI, 2013) .

Sedangkan pemaknaan Ermessen atau Diskresi di dalam Undang-Undang Nomor 30 Tahun 2014 tentang Administrasi Pemerintahan Pasal 1 angka 9 menjelaskan Diskresi adalah Keputusan dan/atau Tindakan yang ditetapkan dan/atau dilakukan oleh Pejabat Pemerintahan untuk mengatasi persoalan konkret yang dihadapi dalam penyelenggaraan pemerintahan dalam hal peraturan perundang-undangan yang memberikan pilihan, tidak mengatur, tidak lengkap atau tidak jelas, dan/atau adanya stagnasi pemerintahan.

Frasa persoalan konkret dapat dimaknai sebagai keadaan yang nyata tidak dibuat-buat, atau peristiwa yang diharuskan untuk menggunakan wewenang diskresi tersebut. Namun perosalan konkret seperti dijelaskan di atas, dapat merujuk kepada penyalahgunaan kewenangan untuk melakukan tindakan-tindakan yang bertentangan dengan kepentingan umum atau untuk menguntungkan kepentingan pribadi, kelompok atau golongan ddan Penyalahgunaan kewenangan untuk mencapai tujuan tertentu melalui penggunaan prosedur lain, disamping itu dapat pula berupa perbuatan yang tidak tepat, dalam hal terdapat beberapa opsi/pilihan tindakan dan perbuatan yang tidak bermanfaat (Permana, 2009).

Sebagaimana dijelasakan sebelumnya. Unsur pengujian yang harus ada jika itu penyalahgunaan wewenang tersebut dapat diuji dengan asas spesialitas, dan sewenang-wenangan unsur yang harus dibuktikan dengan menggunakan asas rasionalitas atau kepantasan. Sedangkan secara penormaan yang dapat menjadi acuan publik dalam menilai peraturan kebijakan berupa legislasi semu seperti sudah dijelaskan di atas maka hal yang dapat di pandang sebagai pelangagran atas UU No. 30 Tahun 2014 tentang Administrasi Pemerintahan tidak sesuai dengan ketentuan Pasal 26, Pasal 27, dan Pasal 28. akibat hukum dari penggunaan Diskresi sebagaimana dimaksud pada ayat (1) menjadi tidak sah apabila. a. 
penggunaan Diskresi tidak sesuai dengan tujuan wewenang yang diberikan; b. Tidak sesuai dengan ketentuan Pasal 26, Pasal 27, dan Pasal 28; dan/atau c. bertentangan dengan AUPB. Akibat dari penggunaan Diskresi sebagaimana dimaksud pada ayat (1) dapat dibatalkan. Tetapi pembuktian penyalahgunaan wewenang dirasa cukup sulit untuk dibuktikan karena unsur penyalahgunaan wewenang dapat diperiksa apabila tindakan tersebut untuk menguntungkan kepentingan pribadi, kelompok atau golongan, penyimpangan dari tujuan umum, penggunaan prosedur lain yang mengakibatkan tindakan tersebut tidak bermanfaat.

Masyarakat diberikan hak untuk melapor atau dalam hal ini melakkan pengaduan sebagaimana dimakud disampaikan secara manual atau secara elektronik. Kemudian Atasan Pejabat menjamin kerahasiaan identitas pelapor, kecuali untuk kepentingan penegakan hukum. Pasal 17 ayat (1) Pengaduan yang disampaikan oleh masyarakat sebagaimana dimaksud dalam Pasal 15 wajib ditindaklanjuti oleh Atasan Pejabat dalam waktu 5 (lima) hari kerja terhitung sejak diterimanya laporan pengaduan. Ayat (2) Dalam melakukan pemeriksaan atas pengaduan masyarakat sebagaimana dimaksud pada ayat (1), Atasan Pejabat wajib berkoordinasi dengan aparat pengawasan intern pemerintah. Ayat (3) Apabila dalam waktu 5 (lima) hari kerja Atasan Pejabat tidak menindaklanjuti pengaduan masyarakat tanpa alasan yang sah, Pejabat Yang Berwenang Mengenakan Sanksi Administratif wajib menjatuhkan Sanksi Administratif kepada Atasan Pejabat sesuai dengan tingkat kesalahannya.

Pengawas Intern yang dimaksud adalah menurut Pasal UU No. 30 Tahun 2014 dilakukan oleh aparat pengawasan intern pemerintah mengawasi terhadap tidak terdapat kesalahan, terdapat kesalahan administratif, atau terdapat kesalahan administratif yang menimbulkan kerugian keuangan negara. Pengawas intern melakukan tindak lanjut dalam bentuk penyempurnaan administrasi sesuai dengan ketentuan peraturan perundang-undangan, apabila menimbulkan kerugian keuangan negara dilakukan pengembalian kerugian keuangan negara paling lama 10 (sepuluh) hari kerja terhitung sejak diputuskan dan diterbitkannya hasil pengawasan. Dengan demikian, diharapkan terwujudnya proses tata kelola pemerintahan yang transparan atau kejelasan mengenai proses penyelenggaraan sesuai dengan prosedur, agar hal tersebut dapat di rasakan kemanfaatan dan tujuannya sehingga warga negara dapat 
memberikan penilaian dan masukan/evaluasi bagi pemerintah, dan tidak lupa pula setiap kebijakan harus berdasarkan hukum tertulis, meskipun tidak tertulis namun bisa diperanggungjawabkan. Dengan demikian pemerintahan yang "patut" adalah pemerintahan yang layak, wajar, pantas, dan baik, elok, teratur, apik, rapi tidak celanya. (Marbun, 1997: 337)

\section{SIMPULAN}

Kepala daerah diberikan hak konstitusional untuk menetapkan peraturan kebijakan, kepala daerah diberikan hak untuk membuat aturan bagi wilayah administratifnya. Peraturan kebijakan tersebut merupakan suatu kebutuhan dalam rangka penyelenggaraan pemerintahan, peraturan kebijakan ini dikenal sebagai legislasi semu yang dapat berupa Surat Edaran (SE), Petunjuk Pelaksana Petunjuk Operasional atau Petunjuuk Teknis, Instruksi, Pengumuman. Parameter atas peraturan kebijakan yang di keluarkan menurut teknisnya melalui asas-asas umum pemerintah yang layak yang dilakukan oleh peradilan tata usaha negara dengan melakukan pengumpulan fakta, penilaian/pengujian terhadap fakta hukum atau peristiwa hukum, memberikan pertimbangan hukum mengenai penerapan asas-asas umum pemerintahan yang layak. Sedangkan unsur yang diuji adalah dengan diuji dengan asas rasionalitas atau kepantasan dan secara isi substansi bertentangan dengan peraturan perundang-undangan yang berlaku. Sedangkan peraturan kebijakan tidak memuat sanksi berupa sanksi pidana, sanksi pemaksa, hal ini karena peraturan kebijakan tidak memuat sanksi tersebut karena sanksi tersebut hanya boleh di muat dalam undang-undang dan peraturan daerah (Perda). Peraturan kebijakan boleh mencantumkan sanksi dalam isi substansinya hanya sebatas sanksi administratif.

\section{DAFTAR RUJUKAN}

Abdul Rasyid Thalib dan Rahmat Bakri. (2013). Analisis Yuridis Asas Freies Ermessen Dalam Menyelenggarakan Fungsi Pajak. Jurnal Ilmu Hukum, 53(9), 1689-1699. https://doi.org/10.1017/CBO9781107415324.004

Chakim, M. L. (2019). PSEUDOWETGEVING. Majalah Konstitusi. http://www.lutfichakim.com/2016/07/pseudowetgeving.html

Damanik, K. I. (2019, October). Pemprov Sumut Bikin Edaran: Asn Yang Diperiksa Kpk Harus Izin Gubernur. DetikNews, 1. 
https://news.detik.com/berita/d-4751026/pemprov-sumut-bikin-edar an-asn-yang-diperiksa-kpk-harus-izin-gubernur

Fitria. (2009). Karakteristik, Pengawasan, Peradilan Admionistrasi, Tindakan Pemerintah. Jurnal Ilmu Hukum, 7(3), 92-104.

HR, Ridwan. (2009). Tiga Dimensi Hukum Adminsitrasi Dan Peradilan Adminstrasi. FH UII Press. . (2014). Diskresi dan Tanggung jawab Pemerintah. FH UII Press. (2017). Hukum Administrasi Negara. PT RajaGrafindo Persada. Huda, N. (2014). Hukum Tata Negara Indonesia Edisi Revisi. PT Raja Grafindo Persada.

Ihsan Badruni Nasution. (2014). Pengujian Peraturan Kebijakan (Beleidsregel) di Mahkamah Agung (Studi Putusan Mahkamah Agung Nomor $23 \mathrm{P} / \mathrm{HUM} / 200$ [Universitas Islam Negeri]. In Universitas Islam Negeri Syarit' Hidayatullah (Vol. 39, Issue 1). https://doi.org/10.4324/9781315853178

IKAHI. (2013). KOMPILASI MAKALAH SEMINAR IKAHI: Tahun 2013-2019. https://books.google.co.id/books?id=Bh64DwAAQBAJ\&redir_esc=y \&hl=id

Keuangan, B. P. dan P. (2014). Kedudukan Aturan Kebijakan (Surat Edaran, Instruksi, Petunjuk Teknis) Dalam Hukum Positif Di Indonesia. Kementerian

Keuangan. https://bppk.kemenkeu.go.id/content/berita/pusdiklat-pajak-kedudu kan-aturan-kebijakan-surat-edaran-instruksi-petunjuk-teknis-dalamhukum-positif-di-indonesia--2019-11-05-64fb4d82/

Manan, B. (2001). Menyongsong Fajar Otonomi Daerah. Pusat Studi Hukum Fakultas Hukum Universitas Islam Indonesia.

Marbun S. F, dan MD, Mahfud. (2011). Pokok-Pokok Hukum Administrasi Negara. Liberty.

Marbun, S.F. (1997). Peradilan Administrasi Negara dan Upaya Administrasi di Indonesia. Liberty Offset.

_ _ _ _ _. (2018). Hukum Administrasi Negara I (Administrative Law I) (Kedua). FH UII Press.

Nugraha, S. (1997). Landasan Teoritis Dan Yuriois Proseour Perizinan Lingkungan Departemen Perhubungan. Hukum Dan Pembangunan, 27(1), 24-32.

https://doi.org/http://dx.doi.org/10.21143/jhp.vol27.no1.525

Permana, T. C. I. (2009). Pengujian Keputusan Diskresi Oleh Pengadilan 
Tata Usaha Negara. In Diponegoro University Institutional Repository. Universitas Diponegoro Semarang.

Radita Ajie. (2016). Batasan Pilihan Kebijakan Pembentuk Undang-Undang (Open Legal Policy) dalam Pembentukan Peraturan Perundang-undangan Berdasarkan Tafsir Putusan Mahkamah Konstitusi. Jurnal Legislasi Indonesia (Indonesian Journal of Legislation), Vol. 13(No.2 Juni), 111-120.

Ridwansyah, M. (2018). Upaya Menemukan Konsep Ideal Hubungan Pusat-Daerah Menurut Undang-Undang Dasar Negara Republik Indonesia Tahun 1945. Jurnal Konstitusi, 14(4), 838. https://doi.org/10.31078/jk1447

Safuan, A. (2020). Bupati Demak Keluarkan Aturan Larangan Bertamu Jam 17.00-19.00. Media Indonesia, 1. https://mediaindonesia.com/read/detail/282232-bupati-demak-keluar kan-aturan-larangan-bertamu-jam-1700-1900

Salim, Z. (2020). Legislasi Semu (pseudowetgeving). Direktori Jenderal Peraturan Perundang-Undangan. http://ditjenpp.kemenkumham.go.id/htn-dan-puu/1299-legislasi-sem u-pseudowetgeving.html

Soemardi, D. (2017). Aspek Hukum dari Wewenang dan Tanggung Jawab. Jurnal Hukum \& Pembangunan, 16(2), 158. https://doi.org/10.21143/jhp.vol16.no2.1198

Syuhudi, I. (2017). Implementasi Asas-Asas Umum Pemerintahan yang Baik Di Lingkungan Peradilan Administrasi Negara. Pena Justisia: Media Komunikasi Dan Kajian Hukum Implementasi, 17(1), 10-19.

Yudhi Setiawan, E. a. (2017). Hukum Administrasi Pemerintahan Teori dan Praktik. PT RajaGrafindo Persada.

Yunus, N. R. (2016). Menciptakan Good and Clean Government. Nur El-Islam, 3(1), 143-175. 